\title{
Reestablishing a stepping-stone population of the threatened elkhorn coral Acropora palmata to aid regional recovery
}

\author{
Ilsa B. Kuffner ${ }^{1, *}$, Anastasios Stathakopoulos ${ }^{1}$, Lauren T. Toth ${ }^{1}$, Lucy A. Bartlett ${ }^{2}$ \\ ${ }^{1}$ US Geological Survey, St. Petersburg Coastal and Marine Science Center, St. Petersburg, Florida 33701, USA \\ ${ }^{2}$ Contracted by Cherokee Nation Technologies to US Geological Survey, St. Petersburg Coastal and Marine Science Center, \\ St. Petersburg, Florida 33701, USA
}

\begin{abstract}
Recovery of the elkhorn coral Acropora palmata is critical to reversing coral reef ecosystem collapse in the western Atlantic, but the species is severely threatened. To gauge potential for the species' restoration in Florida, USA, we conducted an assisted migration experiment where 50 coral fragments of 5 nursery-raised genetic strains (genets) from the upper Florida Keys were moved to 5 sites across $350 \mathrm{~km}$ of the offshore reef. Additionally, 4 fragments from the 1 remaining colony of A. palmata in Dry Tortugas National Park (DRTO) were added to the 2 DRTO experimental sites to test for local adaptation. To measure coral performance, we tracked coral survival, calcification, growth, and condition from May 2018 to October 2019. All 24 corals relocated to the DRTO sites survived and calcified $\sim 85 \%$ faster than the fewer surviving corals transplanted to the 2 upper Keys sites. While coral survival across the entire experiment did not depend on genet, there was a weak but statistically significant genetic effect on calcification rate among the corals relocated to DRTO. The DRTO native genet was among the fastest growing genets, but it was not the fastest, suggesting a lack of local adaptation at this scale. Our results indicate that DRTO, a remote reef system inhabited by the species during the Holocene and located at the nexus of major ocean currents, may be a prime location for reestablishing A. palmata. Assisted migration of $A$. palmata to DRTO could restore a sexually reproducing population in $<10 \mathrm{yr}$, thereby promoting the species' regional recovery.
\end{abstract}

KEY WORDS: Connectivity $\cdot$ Restoration $\cdot$ Ecosystem services $\cdot$ Holocene $\cdot$ Threatened species $\cdot$ Endangered species $\cdot$ Assisted migration $\cdot$ Genetic rescue $\cdot$ Assisted gene flow

\section{INTRODUCTION}

The global loss of species is perhaps the greatest challenge in addressing ecosystem collapse because it is irreversible. To prevent species loss, intervening early, before populations have lost the capacity for self-renewal (e.g. humpback whale), has generally resulted in more effective and efficient conservation outcomes than waiting until drastic interventions, such as captive breeding (e.g. northern white rhinoceros), become necessary (Snyder et al. 1996). How-

${ }^{*}$ Corresponding author: ikuffner@usgs.gov ever, the removal of single, well-understood threats such as hunting is much easier than addressing chronic or pervasive stresses (Hayward 2011). Human imprints on global climate and biogeochemical cycling have driven significant biodiversity loss on land and in the marine realm (Vitousek et al. 1997, Jones et al. 2004), and concerns about extinction now include roughly a third of all coral species (Carpenter et al. 2008). In 2006, Acropora palmata and A. cervicornis were the first corals listed as threatened under the US Endangered Species Act (NMFS-NOAA 
2006), and they were soon after identified as Critically Endangered by the IUCN (Aronson et al. 2008).

The elkhorn coral A. palmata is the only coral species that builds the reef crest habitat zone in the western Atlantic, and it is distinctive regarding its large size: colonies can reach $>5 \mathrm{~m}$ in diameter and $>4 \mathrm{~m}$ in height. Patterns of ecological and geological zonation as described in the mid-20 ${ }^{\text {th }}$ century (Goreau 1959, Geister 1977, Marszalek et al. 1977), characterized by uninterrupted dominance of the 2 Acropora species for thousands of years, no longer exist today in most places (Aronson \& Precht 2001, Aronson et al. 2002, Precht et al. 2004, Wapnick et al. 2004, Toth et al. 2019). Of the 2 species, A. palmata is arguably the more important ecosystem engineer (Macintyre \& Glynn 1976), with some exceptional locations where A. cervicornis built thick Holocene reefs (Macintyre et al. 1977, Aronson et al. 2002). While both species suffered dramatic population declines from a disease pandemic in the late 1970s (Gladfelter 1982, Aronson \& Precht 2001), the decrease in A. palmata is arguably more consequential for reef morphology. Acres of dead corals were left at the reef crest, which in places, persist today in growth position (e.g. Buck Island Reef National Monument, US Virgin Islands), possibly because of a thick rind of crustose coralline algae and secondary cementation (Adey 1975). However, most A. palmata skeletons have been reduced to rubble over the years from a combination of bioerosion (Glynn \& Manzello 2015) and hurricanes (Woodley et al. 1981), leaving flatter, less topographically complex reefs that have become non-accreting throughout the region (Alvarez-Filip et al. 2009, Perry et al. 2015, Kuffner \& Toth 2016). The results of reef degradation and flattening include loss of ecosystem services such as coastal protection from storms, food security from important fisheries, and economic returns from tourism (Costanza et al. 1997, 2014, Spalding et al. 2017, Storlazzi et al. 2019).

The Dry Tortugas coral reef ecosystem, located at a latitude of $24.4^{\circ} \mathrm{N}$, is the westernmost terminus of the Florida reef tract (Fig. 1). This subtropical reef system is separated from other nearby reefs to the east by a

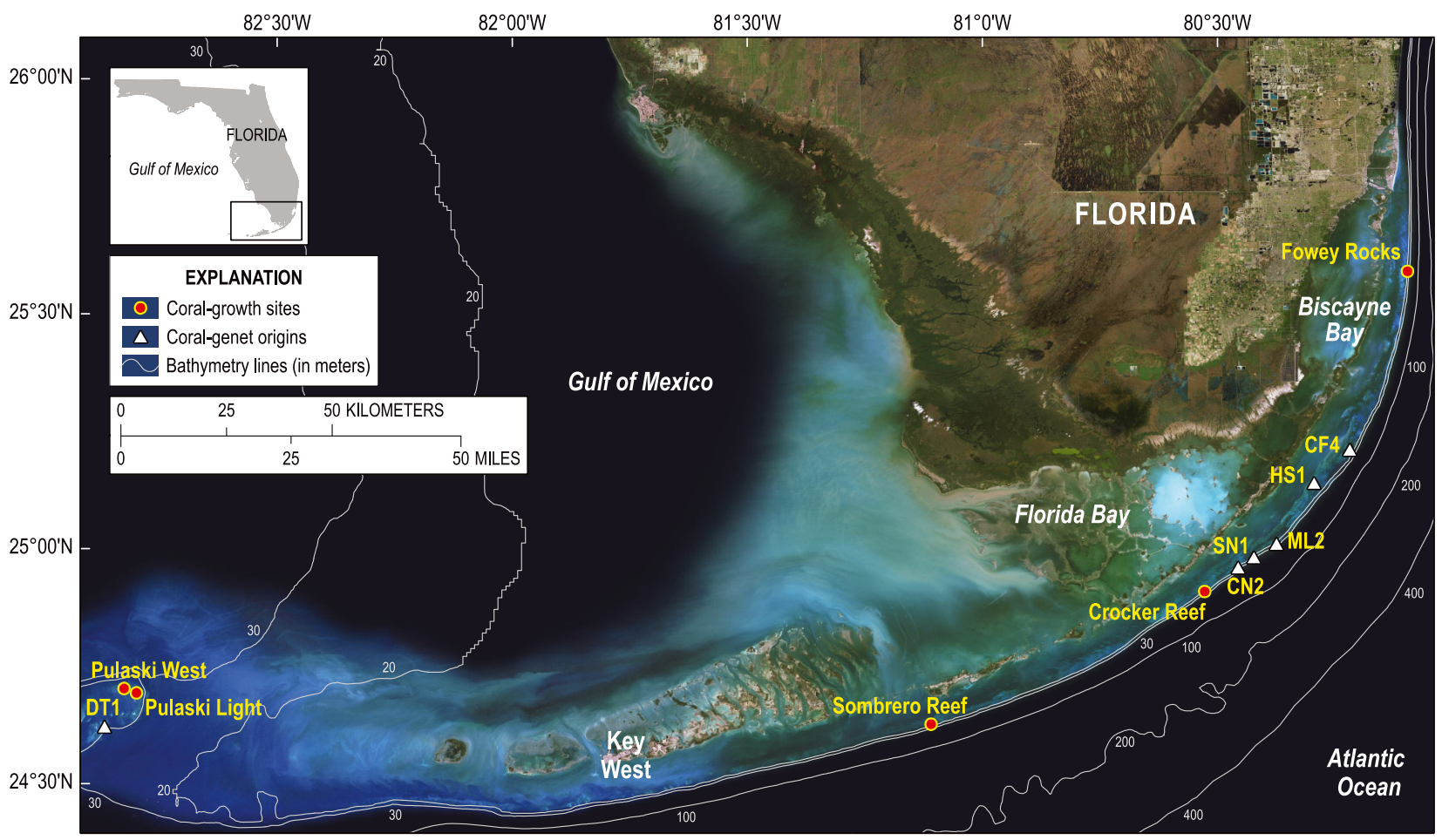

Fig. 1. Sites (white triangles) where Acropora palmata genets were originally harvested by the Coral Restoration Foundation (or The Nature Conservancy in Dry Tortugas) and sites (red circles) where nursery-raised fragments of those genets were transplanted to experimental blocks on the offshore reef. Experimental sites are Pulaski West $\left(24.70^{\circ} \mathrm{N}, 82.80^{\circ} \mathrm{W}\right), \mathrm{Pulaski}$ Shoal Light $\left(24.69^{\circ} \mathrm{N}, 82.77^{\circ} \mathrm{W}\right)$, Sombrero Reef $\left(24.63^{\circ} \mathrm{N}, 81.11^{\circ} \mathrm{W}\right)$, Crocker Reef $\left(24.91^{\circ} \mathrm{N}, 80.53^{\circ} \mathrm{W}\right)$, and Fowey Rocks $\left(25.59^{\circ} \mathrm{N}, 80.10^{\circ} \mathrm{W}\right)$. Genet collection sites are Carysfort Reef $(\mathrm{CF})$, Conch Reef $(\mathrm{CN})$, Dry Tortugas (DT), Horseshoe Reef (HS), Molasses Reef (ML), and Snapper Ledge (SN). Base map is uncopyrighted from World_Imagery; source: Esri, DigitalGloble, GeoEye, Earthstar Geographics, CNES/Airbus DS, USGDA, USGS, AES, Getmapping, Aerogrid, IGN, IGP, Swisstopo, and the 
$25 \mathrm{~m}$ deep, $35 \mathrm{~km}$ wide channel, and as of this writing, it remains free of the stony coral tissue loss disease (SCTLD) that has devastated the coral communities of Florida since 2014 (Precht et al. 2016, Muller et al. 2020). The Dry Tortugas are also remote from human settlements, situated $100 \mathrm{~km}$ west of the nearest city of Key West, USA, and $175 \mathrm{~km}$ north of Havana, Cuba. Recognized early as an area of significance to human and wildlife connectivity, the US military built a fortification in the mid-1800s to defend trading routes that converge at the strategic location, the area was designated as a natural resource refuge in 1908, and the first coral reef research laboratory in the Western Hemisphere was established there in the early 1900 s by the Carnegie Institute (Shinn \& Jaap 2005). The shallow areas of the Dry Tortugas banks, where A. palmata could potentially live today, are contained within Dry Tortugas National Park (DRTO). Where reef coring investigations into the fossil record have occurred, $A$. palmata was not an extensive presence in the Holocene reefs (Shinn et al. 1977, Toth et al. 2019). However, our recent collection and dating have revealed that A. palmata populations were present in DRTO from $\sim 4500$ to $2700 \mathrm{yr}$ BP. In historic times, Agassiz (1885) recorded living populations in areas near Garden Key, but these contracted substantially during the first half of the $20^{\text {th }}$ century (Jaap \& Sargent 1994), and by the 1980s, the population was confined to the existing location where only 1 patch reef persists (Davis 1982, Ruzicka et al. 2010). Genetic analysis originally suggested that the remaining DRTO population was composed of 2 genets (Baums et al. 2005), but later testing of 50 colonies in 2015 showed that only 1 remained (K. Neely, NOVA Southeastern University, pers. comm., 3 May 2020), indicating that today, the species is functionally extinct in the Dry Tortugas. Additionally, populations throughout the Florida Keys have declined precipitously, and there is little evidence of sexual recruitment of new colonies (Williams et al. 2008), necessitating the consideration of restoration interventions in the region (Miller et al. 2016).

Sitting at the nexus of several major ocean currents, the Dry Tortugas are well connected to reefs both upstream in the Caribbean and downstream in the Florida Keys. The Yucatan Current flows northward from the western Caribbean, forms the Loop Current that infiltrates north into the Gulf of Mexico, resumes eastward movement as the Florida Current, and then becomes the Gulf Stream that gains speed and flows north toward Bermuda (Lee et al. 1995). The complex hydrology of the Dry Tortugas area results in dynamic reversals of flow speeds and directions with mesoscale eddies that cause periodic localized upwelling (Lee et al. 1995, Kourafalou et al. 2018). The ocean temperatures experienced by the shallow reefs in DRTO annually average $26.7^{\circ} \mathrm{C}$, which is about $0.6^{\circ} \mathrm{C}$ cooler than other outer reef crest habitats to the east-northeast in the middle and upper Florida Keys reefs at similar depths (Kuffner 2020). Coral larvae are known to be transported by the Loop Current because of settlement to oil rigs throughout the northern Gulf of Mexico (Sammarco et al. 2004), suggesting that DRTO is well connected to other upstream western Atlantic reefs. Similarly, genetic data and ocean current modeling support the conclusion that DRTO's shallow reefs are well connected to the downstream reefs in the main Florida Keys; thus, there is significant potential for these reefs to be a source of coral larvae to the degraded reefs to the north (Serrano et al. 2014).

Here we report on a managed relocation experiment conducted across $350 \mathrm{~km}$ of the Florida reef tract to provide information relevant to the restoration of vestigial populations of A. palmata in the Florida Keys. Five genetically distinct individuals (genets) of A. palmata were sampled and sourced from the Coral Restoration Foundation (CRF, Key Largo, FL) Carysfort Reef coral nursery in the upper Florida Keys and translocated to offshore reef sites including 2 in DRTO, 2 in the Florida Keys National Marine Sanctuary (FKNMS), and 1 in Biscayne National Park (BISC). Additionally, fragments from the 1 extant colony of A. palmata found in DRTO were relocated to the 2 study sites within DRTO. The goal of our study was 2-pronged: (1) to test the feasibility of reestablishing a reproductive population of A. palmata in the Dry Tortugas by adding nurseryraised fragments from reefs in the upper Florida Keys sourced from 5 genetically distinct lineages, and (2) to compare coral growth metrics (calcification rate, height, and planar surface area) and colony condition among translocation sites and genets to explore evidence for genetic differences, environmental drivers, or interaction between genetics and environment in determining coral performance.

\section{MATERIALS AND METHODS}

\subsection{Experimental setup}

The experiment was performed at 5 US Geological Survey (USGS) calcification assessment network sites, 4 of which were previously established (Kuffner et 
al. 2013, 2019) and a fifth that was added as a second site within DRTO. The second DRTO site was placed approximately $2 \mathrm{~km}$ west from the first and further onto the DRTO platform, in December 2016, to add spatial replication in an area that had shown exceptional coral growth in previous experiments with other coral species (Kuffner et al. 2013). The 5 sites are (from west to east) Pulaski Shoal West (PLW) and Pulaski Shoal Light (PLS) in DRTO, Sombrero Key Reef Sanctuary Preservation Area (SMK) and Crocker Reef (CRK) in the FKNMS, and Fowey Rocks (FWY) in BISC (Fig. 1). Small (approximately $5 \times 5 \times 3 \mathrm{~cm})$ Acropora palmata fragments of 5 genets (CF4, CN2, HS1, ML2, and SN1), with enough replicates (ramets) for placing 2 of each genet at each site, were collected by CRF staff at their Carysfort Reef coral nursery on April 24, 2018 (for main Florida Keys sites), and May 6, 2018 (for DRTO sites). The 5 genets, originally sourced from different reefs in the upper Florida Keys (Carysfort Reef [CF], Conch Reef [CN], Horseshoe Reef [HS], Molasses Reef $[\mathrm{ML}]$, and Snapper Ledge [SN]), were chosen by CRF based on the availability of adequate numbers of ramets in the nursery and apparent health of the donor colonies. After delivery by CRF staff, fragments were transported by vehicle in a cooler with seawater-moistened plastic bubble wrap and, upon arrival at an overnight land-based location, placed outside in coolers or buckets with seawater (freshly collected offshore) and aerated overnight. At the 2 DRTO sites, a sixth local genet was included in the experiment. Fragments of opportunity (gathered after storm breakage) from the extant DRTO colony that had been reared in The Nature Conservancy's coral nursery near Garden Key were sampled on May 8, 2018, transported by boat in seawater, and similarly kept in aerated seawater overnight. The DRTO genet was not reciprocally transplanted to the main Florida Keys sites because of logistics and permitting. Coral fragments were mounted onto plastic discs with stainless steel bolts through their centers using epoxy (All-Fix, Cir-Cut) and removably attached to cinderblocks previously installed on the reef (Fig. 2; see Morrison et al. [2013] for detailed methods and diagrams of the experimental setup).

\subsection{Data collection}

Underwater temperature data were recorded every 15 min with $2 \mathrm{HOBO}^{\circledR}$ Water Temp Pro v2 temperature loggers $\left(\right.$ Onset ${ }^{\circledR} ; \pm 0.2^{\circ} \mathrm{C}$ precision) deployed at each offshore reef site for the duration of the study (Kuffner 2020). Just before deployment and every 6 mo thereafter from spring 2018 to fall 2019, corals were removed from their blocks, transported by vessel to land, buoyantly weighed (Jokiel et al. 1978), photographed from the side and top, and measured with calipers (length $\times$ width $\times$ height). Calcification rates (change in dry mass per unit time) were normalized to the planar footprint area of the coral, analogous to the crown spread area of a tree's canopy (Uzoh \& Ritchie 1996), at the start of each weighing interval using the caliper measurements (length $\times$ width) and the formula for the area of an ellipse.

\subsection{Managing risk}

The risks of managed relocation of live corals (Bartz \& Brett 2015, Baums et al. 2019) among the sites extending across $350 \mathrm{~km}$ of the Florida reef tract were considered by the authors, National Park Service, and FKNMS personnel through the scientific research permitting process and were mitigated to the maximum extent possible. We used small, single-branch fragments of coral to reduce invertebrate hitchhikers, transported the fragments on seawater-moistened plastic bubble wrap so that seawater was not transported between sites, and conducted several seawater rinses over non-reef habitat before corals were deployed to the experimental field sites. To minimize risks to DRTO natural resources, we placed our study sites at the northeasternmost corner of the park, approximately $13 \mathrm{~km}$ from the 1 remaining live $A$. palmata colony. Acropora spp. in the Caribbean are not carriers or vectors for SCTLD (Disease Advisory Committee, https://floridadep.gov/rcp/ coral/documents/are-acroporid-corals-potentialvector-stony-coral-tissue-loss-disease), and no SCTLD has been observed in DRTO to date. Regarding the risk of genetic outbreeding depression, A. palmata is a well-mixed metapopulation across the western Caribbean and Florida (Baums et al. 2006), we used donor colonies from populations connected by gene flow and from environmentally similar habitats, we transplanted small fragments that were not of reproductive size, and there is only 1 extant genet in DRTO that is reproductively extinct without conspecifics with which to mate. Thus, we concluded that the risk of outbreeding depression resulting from our experiment is likely small (Baums et al. 2019). 


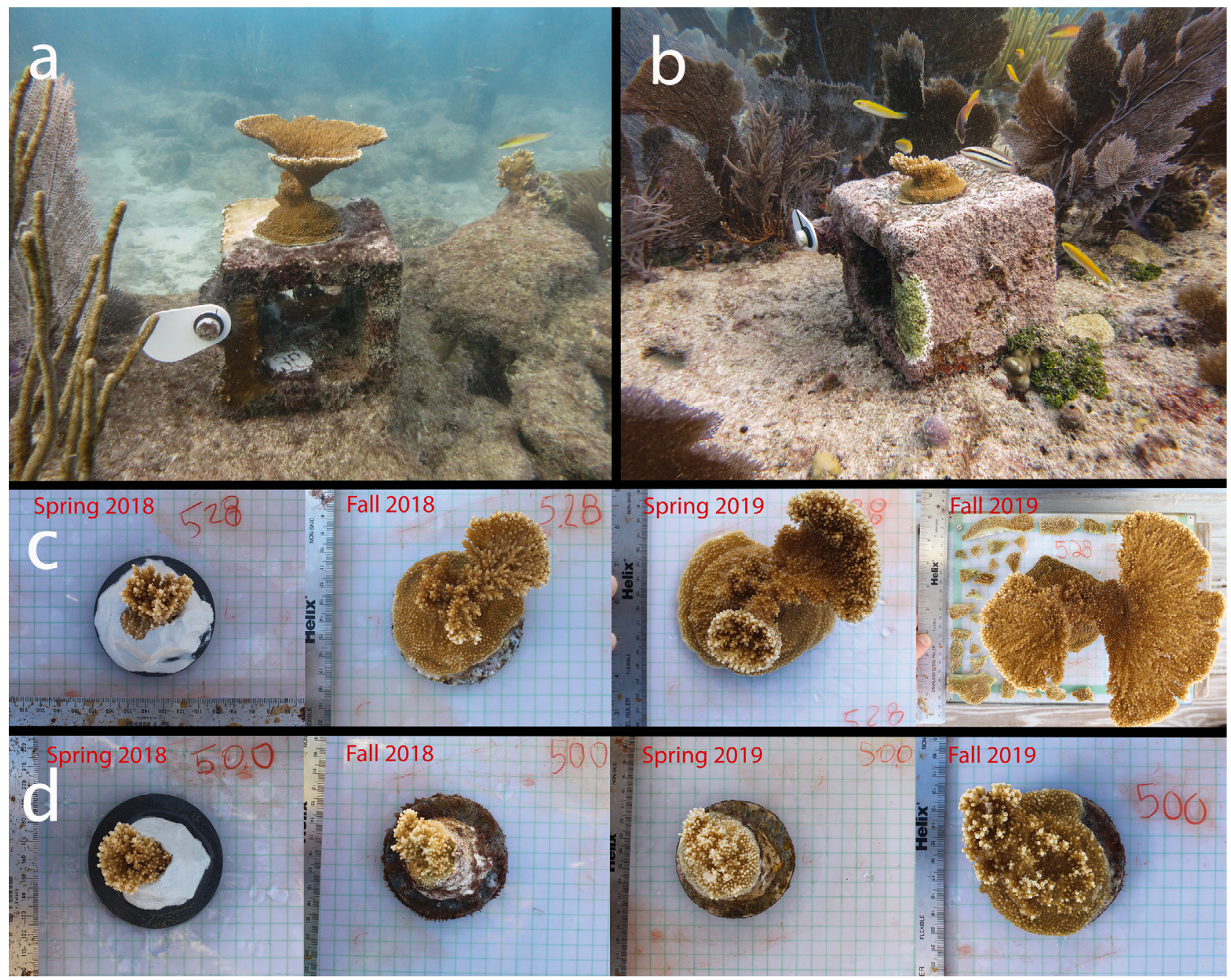

Fig. 2. Representative Acropora palmata colonies (both Coral Restoration Foundation genet CN2) on US Geological Survey calcification assessment network stations at (a) Pulaski Shoal Light, Dry Tortugas National Park, on November 19, 2019, coral no. 528, and (b) Crocker Reef, Florida Keys National Marine Sanctuary, on November 2, 2019, coral no. 500. (c, d) Full time series collages of the same 2 corals. The corals are epoxied to plastic discs with a stainless steel bolt protruding from the bottom so that each can be fastened with a wingnut to the permanently fixed blocks and thus removed for periodic buoyant weighing, photographing, and measuring. For scale, the cement blocks in (a) and (b) are $20 \times 20 \times 20 \mathrm{~cm}$, and (c) and (d) have a ruler included in each image. See https:/doi.org/10.5066/P9KZEGXY for all time-series collages (Kuffner et al. 2020)

\subsection{Statistics}

Statistical analyses were conducted with the software package Statistix ${ }^{\circledR} 10.0$ (Analytical Software). Chi-square tests were used to assess the effects of site and genet on coral survival rates, and a multiple comparisons test for proportions was used to test for differences among sites $(\alpha=0.05)$. Two corals were removed from the chi-square tests because one was dead on arrival (at FWY) and one was lost when a block became dislodged during a storm or from anchor damage (at CRK). The Dry Tortugas genet,
DT1, was also not included because it was not transplanted to the main Florida Keys sites. To test the effects of time and site on each of the growth rate response variables, calcification rate, increase in colony height, and increase in planar footprint area, a general linear model repeated measures ANOVA was conducted, with time (3 levels) and site (5 levels) as fixed effects, the time $\times$ site interaction term included in the model, and the coral identification number as the repeated measures (random) factor. Tukey's HSD all pairwise comparisons tests were used to detect differences among sites and reported 
as groupings not statistically different from each other (where different, all p-values < 0.05). The effect of season (summer vs. winter) could not be tested because the final weighing interval (and subsequent outplanting), scheduled for April 2020, was not completed due to the COVID-19 global pandemic. In the statistical comparisons for the coral growth metrics, corals that died (defined by losing more than $50 \%$ of their live tissue) were removed from the analyses; thus, because of the mortality of genet replicates, the genetic effect was only tested among the corals deployed at the 2 DRTO sites (where survival was $100 \%$ ). Two-way ANOVAs were performed on the 3 growth response variables annualized over the 18 mo experiment, with the fixed effects of site (2 levels), genet (6 levels), and site $\times$ genet interaction term included in the models. Tukey's HSD all pairwise comparisons tests were used to detect differences among genets, and results were reported as groupings not statistically different from each other (where different, all p-values <0.05).

To examine the relationship between increase in colony height and calcification rate, we performed simple linear regression. The distribution of temperature stress among sites and years was examined with a Friedman 2-way nonparametric ANOVA. The assumptions of homoscedasticity and normally distributed residuals were assessed and met without transformation for all variables except for planar footprint area, so those data were rank transformed. For all tests, we considered $\mathrm{p}$-values $<0.05$ to be statistically significant.

\section{RESULTS}

\subsection{Survival}

There was a statistically significant effect of site on Acropora palmata fragment survival during the study (chisquare test statistic $=22.6, p=0.0002$ ), with statistically lower survival rates at FWY (3 of 9 corals) and SMK (4 of 10 corals) than at PLS and PLW, where all corals survived (Tukey's HSD, p < 0.05). There was no genetic effect on survival across the sites (chi-square test statistic $=0.63, \mathrm{p}=0.96)$.

\subsection{Calcification}

The fragments transplanted to the 2 DRTO sites calcified 80 to $85 \%$ faster, averaging $7.9 \mathrm{mg} \mathrm{cm}^{-2} \mathrm{~d}^{-1}$ $\left(29 \mathrm{~kg} \mathrm{~m}^{-2} \mathrm{yr}^{-1}\right)$, than the fragments deployed at the 2 upper Keys sites, where calcification averaged $4.3 \mathrm{mg} \mathrm{cm}^{-2} \mathrm{~d}^{-1}\left(16 \mathrm{~kg} \mathrm{~m}^{-2} \mathrm{yr}^{-1}\right)$; however, while survival was low at SMK, the corals that did survive calcified at levels not statistically different from those in DRTO (Figs. $2 \& 3$, repeated measures ANOVA, site $F_{4,34}=10.4, \mathrm{p}<0.0001$, time $F_{2,68}=1.5, \mathrm{p}=0.23$, site $\times$ time $F_{8,68}=2.4, \mathrm{p}=0.026$, Tukey's HSD, $\mathrm{p}<0.05$ for all pairwise comparisons, PLW and PLS > CRK and FWY). Because of fragment mortality, the genetic effect could only be tested among the corals deployed at the DRTO sites where survival was $100 \%$, which revealed a significant effect of coral genet on calcification rate and no site effect (Fig. 3b, 2-way ANOVA on annualized data, site $F_{1,12}=1.7, \mathrm{p}=0.22$, genet $F_{5,12}=5.04, \mathrm{p}=0.0102$, site $\times$ genotype $F_{5,12}=$ $0.36, \mathrm{p}=0.87)$. Genet HS1 calcified statistically faster
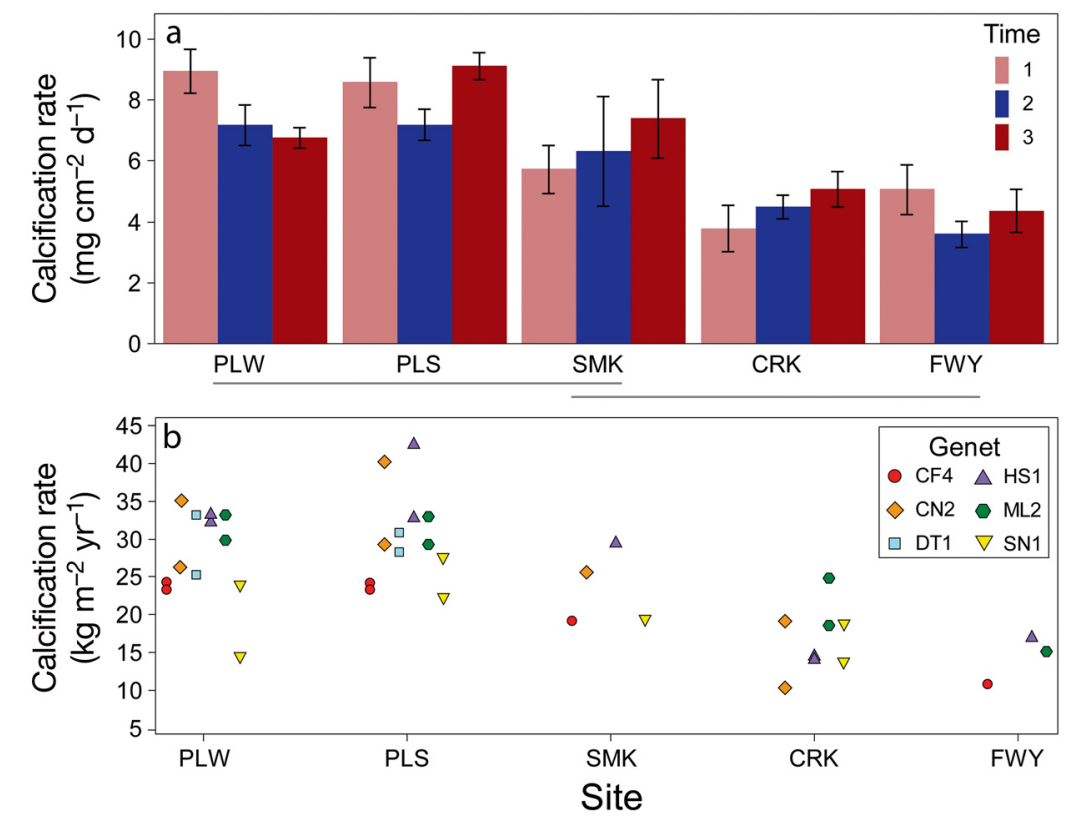

Fig. 3. Calcification rates of Acropora palmata colonies, normalized to planar footprint area, summarized across (a) genets for 3 sequential time intervals (time 1 = summer 2018, time 2 = winter 2019, time 3 = summer 2019) reported in $\mathrm{mg} \mathrm{cm}^{-2} \mathrm{~d}^{-1}$ with error bars $\pm \mathrm{SE}$ and Tukey's HSD groupings under the $x$ axis connecting sites not statistically different at $p<0.05$, and (b) the 3 time intervals, reported in annualized calcification rates $\left(\mathrm{kg} \mathrm{m}^{-2} \mathrm{yr}^{-1}\right)$, for 6 different genets (see Fig. 1 for genet abbreviations) transplanted to experimental stations (Fig. 2) at 5 sites across Florida's outer reef tract. PLW: Pulaski Shoal West; PLS: Pulaski Shoal Light; SMK: Sombrero Reef; CRK: Crocker Reef; FWY: Fowey Rocks. Note that the Dry Tortugas native genet (DT1) was only transplanted to the 2 sites within Dry Tortugas National Park and was not tested at the other sites, and no data points were included in the analyses (and are not shown) for replicates that died (i.e. lost $>50 \%$ of live tissue) 
than CF4 and SN1 but equal to CN2, ML2, and DT1 (Fig. 3b, Tukey's HSD, $\mathrm{p}<0.05$ for all pairwise comparisons).

\subsection{Colony height}

The rate of colony height extension was statistically higher at the 2 DRTO sites, averaging $4.8 \mathrm{~cm}$ $\mathrm{yr}^{-1}$, compared to rates at the 3 main Keys sites, where they averaged $1.5 \mathrm{~cm} \mathrm{yr}^{-1}$ (repeated measures ANOVA, site $F_{4,34}=17.7, \mathrm{p}<0.0001$, time $F_{2,68}=18.2$, $\mathrm{p}<0.0001$, site $\times$ time $F_{8,68}=3.5, \mathrm{p}=0.002$, Tukey's HSD, $\mathrm{p}<0.05$ for all pairwise comparisons, PLS = PLW $>$ SMK $=$ CRK $=$ FWY). Height increase was also greater during the second and third time periods than during the first (Tukey's HSD, $\mathrm{p}<0.05$ for all pairwise comparisons, time $1<$ time $2=$ time 3 ). The significant interaction between time and site reflects the observation that the corals in DRTO encrusted the plates during the first time period, then grew up and branched during the subsequent year, whereas the corals at the other sites were slower to completely encrust the plates and did not produce substantial branches (Fig. 2, also see time series photographs in Kuffner et al. 2020). Among the corals placed at the DRTO sites, there was also a statistically significant effect of genet on colony height extension (2-way ANOVA on annualized data, site $F_{1,12}=0.64, \mathrm{p}=0.44$, genet $F_{5,12}=6.59, \mathrm{p}=0.0036$, site $\times$ genotype $F_{5,12}=1.06, \mathrm{p}=0.43$ ). Genet ML2 grew taller than SN1 (Tukey's HSD, p < 0.05). The relationship between annualized calcification rate $\left(\mathrm{kg} \mathrm{m}^{2} \mathrm{yr}^{-1}\right)$ and change in colony height $\left(\mathrm{cm} \mathrm{yr}^{-1}\right)$ for the 24 corals at DRTO was positive and statistically significant (simple linear regression equation: $\Delta$ height $=-0.0372+0.1655$ (calcification rate), $t=4.9, \mathrm{p}<0.0001$, and $\mathrm{r}^{2}=0.52$ ), suggesting that measuring change in colony height (easy to measure) could be a good phenotypic growth metric for estimating coral calcification rates (difficult to measure) for this species.

\subsection{Colony planar footprint}

Corals increased the planar area they occupied faster at the 2 DRTO sites, averaging $96 \mathrm{~cm}^{2} \mathrm{yr}^{-1}$, than at the Florida Keys sites, where they averaged $15 \mathrm{~cm}^{2} \mathrm{yr}^{-1}$ (repeated measures ANOVA on ranktransformed data, site $F_{4,34}=42.9, \mathrm{p}<0.0001$, time $F_{2,68}=27.1, \mathrm{p}<0.0001$, site $\times$ time $F_{8,68}=0.9, \mathrm{p}=0.52$ ， Tukey's HSD, $\mathrm{p}<0.05$ for all pairwise comparisons,
PLS $=$ PLW $>$ SMK $=$ CRK $=$ FWY). Planar footprint increase was also greater during the third time period than during the first and second (Tukey's HSD, $p<0.05$, time $3>$ time $1=$ time 2 ). Within the DRTO corals, there was no significant effect of site, genet, or the interaction on change in planar footprint area of the colonies (2-way ANOVA on annualized data, site $F_{1,12}=0.38, \mathrm{p}=0.55$, genet $F_{5,12}=1.9$, $\mathrm{p}=0.16$, site $\times$ genotype $F_{5,12}=0.46, \mathrm{p}=0.80$ ).

\subsection{Observations of stress and predation}

The amount of heat stress experienced by the corals, as defined by number of days that mean daily underwater temperature exceeded the A. palmataspecific bleaching threshold temperature of $31.0^{\circ} \mathrm{C}$ (Williams et al. 2017), did not vary statistically between years or sites (Fig. 4; years: Friedman statistic $=1.8$, chi-square approximation $\mathrm{p}=0.18$, sites: Friedman statistic $=5.6$, chi-square approximation $\mathrm{p}=0.23)$. Notably, at Sombrero Reef during the first year, there was a spike in temperature, with 2 consecutive days over $32^{\circ} \mathrm{C}\left(32.4\right.$ and $32.5^{\circ} \mathrm{C}$ on July 17 and 18,2018, respectively). Three corals were noted as pale during our October 2018 visit at Sombrero. The predatory snail Coralliophila abbreviata was observed feeding on 2 experimental colonies at FWY on May 9, 2019. Time series photographs of all corals, as well as all raw data and metadata, are published in Kuffner et al. (2020).

\section{DISCUSSION}

Our experiment demonstrated that 5 Acropora palmata genets sourced from the upper Florida Keys survived and flourished when transplanted to the Dry Tortugas reef system, $300 \mathrm{~km}$ away. Not only did all 5 genets show $100 \%$ survival at DRTO after $18 \mathrm{mo}, 3$ of the genets grew at statistically equivalent calcification rates compared to the 1 remaining extant DRTO genet, suggesting that adaptation to local-scale environmental differences (Kenkel et al. 2015) may not be a concern for this species on the scale of hundreds of kilometers across the Florida reef tract. With the successful introduction of 5 new genets, our translocation experiment has potentially supplied the remaining native DRTO genet with prospective mates, possibly rescuing it from an extreme case of the Allee effect (Knowlton 2001). If the relocated corals succeed in growing into a robust population and/or more are brought in, the 


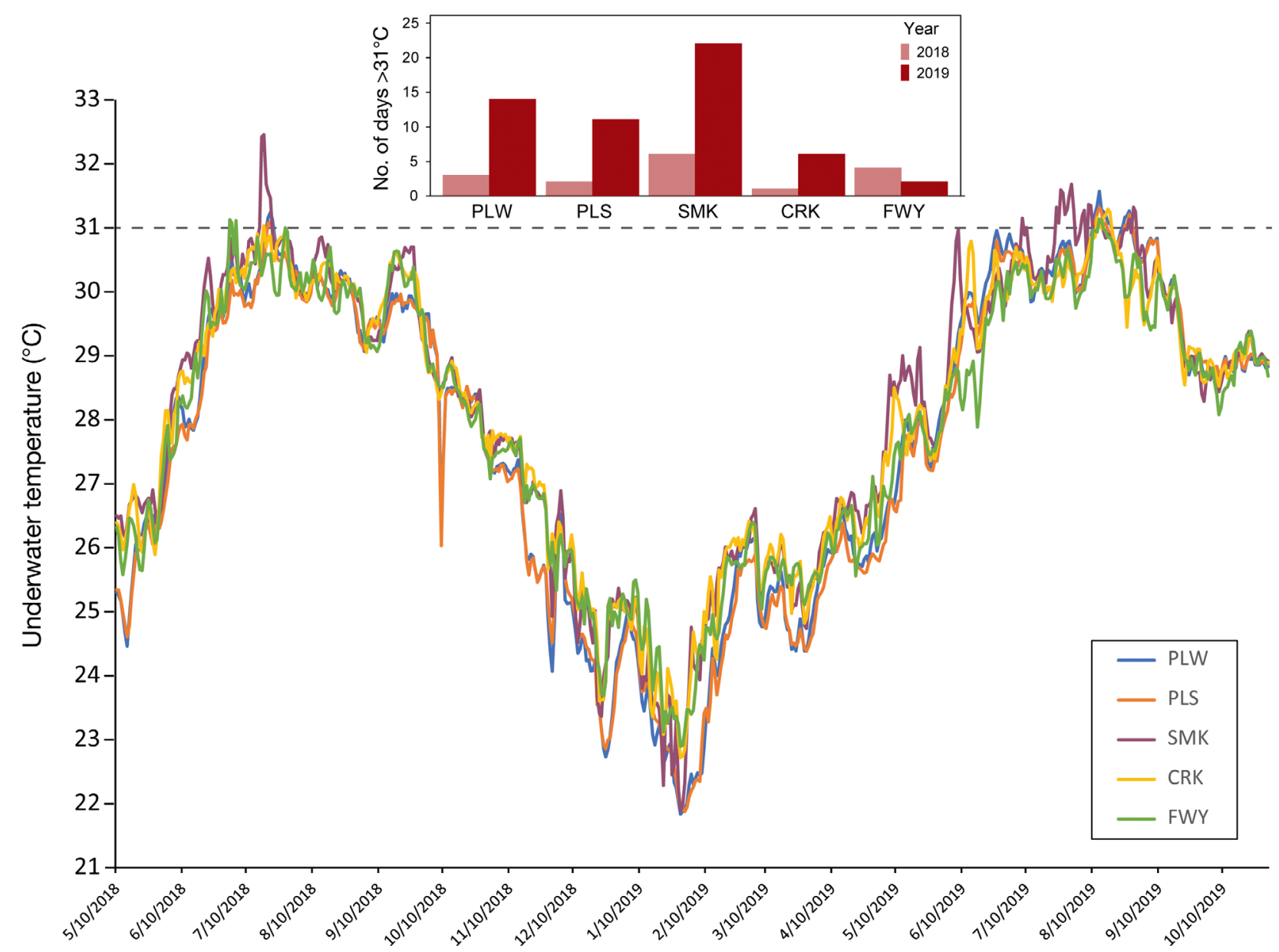

Fig. 4. Underwater temperature at the 5 experimental translocation sites (Kuffner 2020). Inset bar graph shows number of days with daily mean temperature $>31.0^{\circ} \mathrm{C}$ (dashed gray line) in 2018 and 2019. Dates are mo/d/yr. Site abbreviations as in Fig. 3

DRTO genet, which by its persistence has proven resilient to local stresses such as cold temperature anomalies (Davis 1982) and other factors unique to its placement in the subtropical Gulf of Mexico (Jaap 2015), may contribute to future spawning events and thereby pass along any adaptive alleles that it harbors.

The same genets that flourished when moved to the Dry Tortugas did not survive or grow as well when relocated to the 2 reefs in the upper Keys closest to where the colonies were originally collected to be raised in nurseries, and it is unclear why this was so. A. palmata populations in the Florida Keys have continued to contract since the original white-band disease event in the 1980s (Williams et al. 2008, 2014, Miller et al. 2016), and more generally, live coral cover on offshore reefs has declined (Ruzicka et al. 2013). Several A. palmata reefs are in a state where only a few remnant colonies remain (Williams et al. $2008,2014)$, sometimes representing a single genet
(Baums et al. 2005, 2006), indicating Allee effects and both asexual and sexual recruitment failure as likely mechanisms inhibiting population recovery (Williams et al. 2008). Our results seem to indicate that despite having originated in the upper Keys, these genets are no longer able to flourish in their natal habitat, suggesting that sexual recombination, assisted gene flow, and subsequent natural selection may be required for the species to persist in this region. The geographic significance of DRTO as an upstream site to the degraded populations in the upper Florida Keys highlights the potential value of DRTO as a source of larvae for the rest of the Keys, and genetic data from other coral species indicate widespread connectivity at this scale (Shearer et al. 2009, Serrano et al. 2014).

The management of coral reef ecosystems has for several decades been dominated by the establishment of marine protected areas, which set some restrictions on human behavior (primarily fishing) in 
spaces set aside as parks or conservation refuges. This management approach has successfully increased fish biomass, abundance, and/or diversity (Jennings \& Polunin 1996, Chapman \& Kramer 1999, Halpern \& Warner 2002, Ault et al. 2006), but evidence showing concomitant cascading effects on benthic (coral) communities has remained elusive (Toth et al. 2014, Bruno et al. 2019), as has achievement of wider socioeconomic sustainability in the absence of good governance (Sale et al. 2014). Recovery from mass coral mortality events, driven mainly by coral diseases and bleaching (Aronson \& Precht 2006, Eakin et al. 2010), has not demonstrably been mitigated through marine spatial planning alone. Thus, new, more aggressive restoration and intervention methods are being considered and pursued (Hoegh-Guldberg et al. 2008, van Oppen et al. 2017). It is now recognized that nursery-raised corals may be an essential element to scaling up efforts to make measurable progress in achieving ecosystemscale reef restoration using a wide portfolio of intervention strategies (National Academies of Sciences, Engineering, and Medicine 2019).

The importance of genetic effects on coral growth metrics was first suggested by restoration practitioners identifying certain genets as winners (growing faster and more robustly compared to others) in nursery and outplant settings. While our sample size at each site was only $n=2$, our results contribute to the growing body of evidence documenting variability in growth metrics among coral genets for A. cervicornis (Drury et al. 2017, Kuffner et al. 2017, Lohr \& Patterson 2017) and A. palmata (Pausch et al. 2018). Results showing that other important phenotypes vary among genets, including thermal tolerance (Kenkel et al. 2013, Lohr \& Patterson 2017, Williams et al. 2017, Pausch et al. 2018) and disease resistance (Muller et al. 2018, Miller et al. 2019), are encouraging and indicate that a substantial amount of intraspecies genetic variation exists upon which natural selection can act (Dixon et al. 2015, Baums et al. 2019). It might be tempting to identify and focus restoration efforts on such supercorals. However, while selective breeding experiments with genets showing promise in desirable phenotypes are important to increase our understanding of trait-based heredity and evolutionary processes, we argue that the creation of supercorals for restoration purposes could easily backfire because of phenotypic tradeoffs (Ladd et al. 2017) and because ocean conditions will continue to change rapidly and may nullify traitbased advantages (Muller et al. 2018). Thus, if selective breeding is done at the expense of collective genetic diversity within species at restoration sites, it could have undesirable effects. It is less important to asexually propagate and preferentially outplant genets shown to be winners in today's nurseries and oceans than it is to know they exist and use them as broodstock for larval propagation aimed at maximizing recombination of genetic material (Baums et al. 2019).

Our results suggest that something about the environment in the northeastern portion of DRTO enhanced the survival and growth of $A$. palmata. Other species of coral have shown higher growth rates in the Dry Tortugas compared to the main Florida Keys, including Siderastrea siderea (Kuffner et al. 2013) and in our recent work on Porites astreoides, and there are several possible explanations for the pattern. An obvious variable relevant because of regionally increasing ocean temperatures (Kuffner et al. 2015, Manzello 2015) is simply that the in situ temperatures are on average about $0.6^{\circ} \mathrm{C}$ cooler in DRTO than at the main Florida Keys reefs; however, moderate thermal stress during our experiment was experienced across all 5 sites during both years without statistical difference among them, including at the 2 DRTO sites (Fig. 4). The strength of water flow could also be contributing to among-site differences, evidenced by the fact that diving at PLS is challenging because of strong currents and the site is ideally accessed at slack tide. However, this was not our experience at PLW, and calcification rates between these 2 DRTO sites were not statistically different (Fig. 3). Another hypothesis to test is that corals may benefit from nutritional subsidies from periodic upwelled waters containing more abundant or higher quality plankton being delivered to the shallow Dry Tortugas. Shulzitski et al. (2016), for example, showed that larval fish collected from inside high-productivity Tortugas eddies had enhanced survival and physiological condition compared to those outside eddies in the oligotrophic Florida Current. Corals that are well fed have more energy reserves and thus may be less sensitive to stressors including ocean acidification and thermal anomalies (Schoepf et al. 2013). Additionally, some coral species can up-regulate heterotrophic feeding during times of stress (Grottoli et al. 2006). However, other differences among the sites, such as in water quality variables and amount of human interaction, cannot be ruled out at this time in explaining the high growth rates we observed in the Dry Tortugas.

New subfossil evidence from reef drilling studies and surface collections on the Tortugas platform suggests that although A. palmata was relatively rare in 
DRTO for the last $8000 \mathrm{yr}$ (Toth et al. 2019), it was present for nearly $2000 \mathrm{yr}$ in this area, with our samples dating from $\sim 4500$ to $2700 \mathrm{yr}$ BP. The disappearance of the species generally coincides with a regionwide shutdown of reef accretion by $3000 \mathrm{yr}$ BP (Toth et al. 2018). Hypothesized to have resulted from climatic cooling in the late Holocene across the region (Toth et al. 2018), this suggests that the late Holocene has been unhospitable to this cold-sensitive genus (Porter et al. 1982) at this location. With increasing ocean temperatures in the region (Kuffner et al. 2015), this location may once again support A. palmata, as observed for its congener, A. cervicornis, in southeastern Florida (Precht \& Aronson 2004). A. palmata has also recently been observed on the highlatitude reefs of the Flower Garden Banks, where it had been absent since the relatively warm climate of $\sim 10000$ to 7000 yr BP (Precht et al. 2014). Similarly, in the Pacific, recent expansion of several coral species has followed the northward-flowing Kuroshio Current in Japan (Yamano et al. 2011).

Our results indicate that assisted migration (i.e. reintroduction in this case) across a species' historic or Holocene range (Toth et al. 2019) can assist managers in achieving the goals outlined in species recovery plans by reducing Allee effects, increasing the potential for sexual reproduction, and thus increasing the potential for subsequent recruitment and natural selection (NMFS 2015). This may be particularly relevant to subtropical reefs, where the natural expansion of species' ranges into areas until recently too cold provides evidence that humans could assist the movement of populations as ocean conditions continue to warm at rates unprecedented during the Holocene (Marcott et al. 2013) —indeed, likely too fast for coral species to respond on their own because of decades-long generation times. However, naturally expanding populations are bringing their predators and pests with them (Yamano et al. 2011), so it behooves managers to ensure that reefs chosen for stepping-stone reintroductions are places where ecological processes, including predator-prey relationships, remain intact (Shaver \& Silliman 2017, Ladd et al. 2018). Nonetheless, the Holocene record unlocks a valuable tool in coral restoration planning (Toth et al. 2019) as conditions become more like the mid-Holocene (Marcott et al. 2013) and the brief late-Holocene warm period from 1400 to $1000 \mathrm{yr}$ BP (Richey et al. 2007). Since oceanic currents, seasonality, and other local-scale geophysical patterns dictated by location and ocean floor morphology are likely to be similar to those in the past, it could be very instructive to examine how species distribution patterns varied over the past millennia in defining place-based and species-specific restoration strategies (Toth et al. 2019).

In conclusion, our findings suggest that assisted migration, guided by historic and Holocene range extensions and aimed at providing stepping-stone populations to invigorate sexual reproduction and reef connectivity, could be a useful tool in the recovery of $A$. palmata and, hence, ecosystem restoration. However, reef restoration may only be a stop-gap mechanism to help marine species persist during the time period yet to be defined by the climate change commitment (Wigley 2005), which is ever changing with continued perturbations to the global carbon cycle (Mackenzie \& Lerman 2006). Depending on the climate scenario realized (Meehl et al. 2005), the ocean environment could progress quickly through and beyond the bounds of climate variability experienced during the mid- to late Holocene, potentially rendering ecosystem restoration a futile endeavor.

Acknowledgements. The study was funded by the USGS Coastal and Marine Hazards and Resources Program of the Natural Hazards Mission Area. We thank the Coral Restoration Foundation, including Amelia Moura, Jessica Levy, and Kayla Ripple, for providing the nursery-raised Acropora palmata fragments to conduct our study. We are most grateful to Meaghan Johnson, Kayla Nimmo, Glenn Simpson, and Amanda Bourque of the National Park Service for their support. For field and logistics help, we thank Beth Lenz and B. J. Reynolds. We also thank Jennifer Moore of the National Marine Fisheries Service and 3 anonymous reviewers for their highly constructive suggestions that improved the manuscript. The study was conducted under scientific permits from the FKNMS (FKNMS-2016-085-A1 and FKNMS-2019-139) and the National Park Service (BISC2018-SCI-0014, BISC-2019-SCI-0010, DRTO-2017-SCI-0001, and DRTO-2019-SCI-0005). Any use of trade, firm, or product names is for descriptive purposes only and does not imply endorsement by the US Government.

\section{LITERATURE CITED}

Adey WH (1975) The algal ridges and coral reefs of St. Croix, their structure and Holocene development. Atoll Res Bull 187:1-67

Agassiz A (1885) Explorations of the surface fauna of the Gulf Stream, under the auspices of the United States Coast Survey. II. The Tortugas and Florida reefs. Mem Am Acad Arts Sci 11:107-133

Alvarez-Filip L, Dulvy NK, Gill JA, Cote IM, Watkinson AR (2009) Flattening of Caribbean coral reefs: region-wide declines in architectural complexity. Proc R Soc B 276: 3019-3025

Aronson RB, Precht WF (2001) White-band disease and the changing face of Caribbean coral reefs. Hydrobiologia 460:25-38

Aronson RB, Precht WF (2006) Conservation, precaution, and Caribbean reefs. Coral Reefs 25:441-450 
Aronson RB, Macintyre IG, Precht WF, Murdoch TJT, Wapnick CM (2002) The expanding scale of species turnover events on coral reefs in Belize. Ecol Monogr 72:233-249

Aronson R, Bruckner A, Moore J, Precht B, Weil E (2008) Acropora palmata. The IUCN Red List of Threatened Species 2008: e.T133006A3536699. http://dx.doi.org/10.2305/ IUCN.UK.2008.RLTS.T133006A3536699.en (accessed 07 May 2020)

Ault JS, Smith SG, Bohnsack JA, Luo J, Harper DE, McClellan DB (2006) Building sustainable fisheries in Florida's coral reef ecosystem: positive signs in the Dry Tortugas. Bull Mar Sci 78:633-654

Bartz RJ, Brett A (2015) Preserving reef-building coral genetic resources with assisted migration: balancing precaution and risk. Univ Miami Natl Secur Armed Conflict Law Rev 6:206-232. https://repository.law.miami. edu/umnsac/vol6/iss1/15 (accessed Dec 2020)

Baums IB, Miller MW, Hellberg ME (2005) Regionally isolated populations of an imperiled Caribbean coral, Acropora palmata. Mol Ecol 14:1377-1390

Baums IB, Miller MW, Hellberg ME (2006) Geographic variation in clonal structure in a reef-building Caribbean coral, Acropora palmata. Ecol Monogr 76:503-519

Baums IB, Baker AC, Davies SW, Grottoli AG and others (2019) Considerations for maximizing the adaptive potential of restored coral populations in the western Atlantic. Ecol Appl 29:e01978

Bruno JF, Côté IM, Toth LT (2019) Climate change, coral loss, and the curious case of the parrotfish paradigm: Why don't marine protected areas improve reef resilience? Annu Rev Mar Sci 11:307-334

Carpenter KE, Abrar M, Aeby G, Aronson RB and others (2008) One-third of reef-building corals face elevated extinction risk from climate change and local impacts. Science 321:560-563

* Chapman MR, Kramer DL (1999) Gradients in coral reef fish density and size across the Barbados Marine Reserve boundary: effects of reserve protection and habitat characteristics. Mar Ecol Prog Ser 181:81-96

* Costanza R, d'Arge R, de Groot R, Farber S and others (1997) The value of the world's ecosystem services and natural capital. Nature 387:253-260

Costanza R, de Groot R, Sutton P, van der Ploeg S and others (2014) Changes in the global value of ecosystem services. Glob Environ Change 26:152-158

Davis GE (1982) A century of natural change in coral distribution at the Dry Tortugas: a comparison of reef maps from 1881 and 1976. Bull Mar Sci 32:608-623

Dixon GB, Davies SW, Aglyamova GA, Meyer E, Bay LK, Matz MV (2015) Genomic determinants of coral heat tolerance across latitudes. Science 348:1460-1462

* Drury C, Manzello D, Lirman D (2017) Genotype and local environment dynamically influence growth, disturbance response and survivorship in the threatened coral, Acropora cervicornis. PLOS ONE 12:e0174000

Eakin CM, Morgan JA, Heron SF, Smith TB and others (2010) Caribbean corals in crisis: record thermal stress, bleaching, and mortality in 2005. PLOS ONE 5:e13969

Geister J (1977) The influence of wave exposure on the ecological zonation of Caribbean coral reefs. Proc 3rd Int Coral Reef Symp 1:23-29

Gladfelter WB (1982) White-band disease in Acropora palmata: implications for the structure and growth of shallow reefs. Bull Mar Sci 32:639-643

Glynn PW, Manzello DP (2015) Bioerosion and coral reef growth: a dynamic balance. In: Birkeland C (ed) Coral reefs in the Anthropocene. Springer, Dordrecht, p 67-97 *Goreau TF (1959) The ecology of Jamaican coral reefs I. Species composition and zonation. Ecology 40:67-90

Grottoli AG, Rodrigues LJ, Palardy JE (2006) Heterotrophic plasticity and resilience in bleached corals. Nature 440: 1186-1189

* Halpern BS, Warner RR (2002) Marine reserves have rapid and lasting effects. Ecol Lett 5:361-366

Hayward MW (2011) Using the IUCN Red List to determine effective conservation strategies. Biodivers Conserv 20: 2563-2573

Hoegh-Guldberg O, Hughes L, McIntyre S, Lindenmayer DB, Parmesan C, Possingham HP, Thomas CD (2008) Assisted colonization and rapid climate change. Science 321:345-346

* Jaap WC (2015) Stony coral (Milleporidae and Scleractinia) communities in the eastern Gulf of Mexico: a synopsis with insights from the Hourglass collections. Bull Mar Sci 91:207-253

Jaap WC, Sargent FJ (1994) The status of the remnant population of Acropora palmata (Lamarck, 1816) at Dry Tortugas National Park, Florida, with a discussion of possible causes of changes since 1881. In: Ginsburg RN (ed) Proceedings of the colloquium on global aspects of coral reefs: health, hazards, and history. RSMAS, University of Miami, Miami, FL, p 101-105

Jennings S, Polunin NVC (1996) Impacts of fishing on tropical reef ecosystems. Ambio 25:44-49

Jokiel PL, Maragos JE, Franzisket L (1978) Coral growth: buoyant weight technique. In: Stoddart DR, Johannes RE (eds) Coral reefs: research methods. UNESCO, Paris, p 529-541

Jones GP, McCormick MI, Srinivasan M, Eagle JV (2004) Coral decline threatens fish biodiversity in marine reserves. Proc Natl Acad Sci USA 101:8251-8253

Kenkel CD, Goodbody-Gringley G, Caillaud D, Davies SW, Bartels E, Matz MV (2013) Evidence for a host role in thermotolerance divergence between populations of the mustard hill coral (Porites astreoides) from different reef environments. Mol Ecol 22:4335-4348

K Kenkel CD, Almanza AT, Matz MV (2015) Fine-scale environmental specialization of reef-building corals might be limiting reef recovery in the Florida Keys. Ecology 96: 3197-3212

Knowlton N (2001) The future of coral reefs. Proc Natl Acad Sci USA 98:5419-5425

Kourafalou VH, Androulidakis YS, Kang H, Smith RH, ValleLevinson A (2018) Physical connectivity between Pulley Ridge and Dry Tortugas coral reefs under the influence of the Loop Current/Florida Current system. Prog Oceanogr 165:75-99

Kuffner IB (2020) Underwater temperature on off-shore coral reefs of the Florida Keys, U.S.A. (ver. 5.0, April 2020). US Geological Survey Data Release. https://doi.org/10. 5066/F71C1TZK

Kuffner IB, Toth LT (2016) A geological perspective on the degradation and conservation of western Atlantic coral reefs. Conserv Biol 30:706-715

* Kuffner IB, Hickey TD, Morrison JM (2013) Calcification rates of the massive coral Siderastrea siderea and crustose coralline algae along the Florida Keys (USA) outerreef tract. Coral Reefs 32:987-997

Kuffner IB, Lidz BH, Hudson JH, Anderson JS (2015) A century of ocean warming on Florida Keys coral reefs: his- 
toric in situ observations. Estuaries Coasts 38:1085-1096 Kuffner IB, Bartels E, Stathakopoulos A, Enochs IC, Kolodziej G, Toth LT, Manzello DP (2017) Plasticity in skeletal characteristics of nursery-raised staghorn coral, Acropora cervicornis. Coral Reefs 36:679-684

Kuffner IB, Toth LT, Hudson JH, Goodwin WB, Stathakopoulos A, Bartlett LA, Whitcher EM (2019) Improving estimates of coral reef construction and erosion with in situ measurements. Limnol Oceanogr 64:2283-2294

Kuffner IB, Stathakopoulos A, Toth LT, Bartlett LA (2020) Experimental coral-growth data and time-series imagery for Acropora palmata in the Florida Keys, U.S.A. US Geological Survey Data Release. https://doi.org/10.5066/ P9KZEGXY

Ladd MC, Shantz AA, Bartels E, Burkepile DE (2017) Thermal stress reveals a genotype-specific tradeoff between growth and tissue loss in restored Acropora cervicornis. Mar Ecol Prog Ser 572:129-139

Ladd MC, Miller MW, Hunt JH, Sharp WC, Burkepile DE (2018) Harnessing ecological processes to facilitate coral restoration. Front Ecol Environ 16:239-247

* Lee TN, Leaman K, Williams E, Berger T, Atkinson L (1995) Florida Current meanders and gyre formation in the southern Straits of Florida. J Geophys Res 100:8607-8620

Lohr KE, Patterson JT (2017) Intraspecific variation in phenotype among nursery-reared staghorn coral Acropora cervicornis (Lamarck, 1816). J Exp Mar Biol Ecol 486: 87-92

Macintyre IG, Glynn PW (1976) Evolution of modern Caribbean fringing reef, Galeta Point, Panama. AAPG Bull 60: 1054-1072

Macintyre IG, Burke RB, Stuckenrath R (1977) Thickest recorded Holocene reef section, Isla Pérez core hole, Alacran Reef, Mexico. Geology 5:749-754

Mackenzie FT, Lerman A (2006) Carbon in the geobiosphere-Earth's outer shell. Springer, Dordrecht

Manzello DP (2015) Rapid recent warming of coral reefs in the Florida Keys. Sci Rep 5:16762

Marcott SA, Shakun JD, Clark PU, Mix AC (2013) A reconstruction of regional and global temperature for the past 11,300 years. Science 339:1198-1201

Marszalek DS, Babashoff G, Noel MR, Worley DR (1977) Reef distribution in South Florida. Proc 3rd Int Coral Reef Symp 2:223-229

Meehl GA, Washington WM, Collins WD, Arblaster JM and others (2005) How much more global warming and sea level rise? Science 307:1769-1772

Miller MW, Kerr K, Williams DE (2016) Reef-scale trends in Florida Acropora spp. abundance and the effects of population enhancement. PeerJ 4:e2523

Miller MW, Colburn PJ, Pontes E, Williams DE, Bright AJ, Serrano XM, Peters EC (2019) Genotypic variation in disease susceptibility among cultured stocks of elkhorn and staghorn corals. PeerJ 7:e6751

* Morrison JM, Kuffner IB, Hickey TD (2013) Methods for monitoring corals and crustose coralline algae to quantify in-situ calcification rates. US Geological Survey Open-File Report 2013-1159. http://pubs.usgs.gov/of/ 2013/1159/

Muller EM, Bartels E, Baums IB (2018) Bleaching causes loss of disease resistance within the threatened coral species Acropora cervicornis. eLife 7:e35066

Muller EM, Sartor C, Alcaraz NI, van Woesik R (2020) Spatial epidemiology of the stony-coral-tissue-loss disease in Florida. Front Mar Sci 7:163
National Academies of Sciences, Engineering, and Medicine (2019) A research review of interventions to increase the persistence and resilience of coral reefs. National Academies Press, Washington, DC

NMFS (National Marine Fisheries Service) (2015) Recovery plan for elkhorn (Acropora palmata) and staghorn ( $A$. cervicornis) corals. Prepared by the Acropora Recovery Team for the National Marine Fisheries Service, Silver Spring, MD. https://repository.library.noaa.gov/view/ noaa/8950 (accessed 3 Jun 2020)

NMFS-NOAA (2006) Endangered and threatened species: final listing determinations for elkhorn coral and staghorn coral. Fed Regist 71:26852-26861. https://www. federalregister.gov/d/06-4321

Pausch RE, Williams DE, Miller MW (2018) Impacts of fragment genotype, habitat, and size on outplanted elkhorn coral success under thermal stress. Mar Ecol Prog Ser 592:109-117

* Perry CT, Steneck RS, Murphy GN, Kench PS, Edinger EN, Smithers SG, Mumby PJ (2015) Regional-scale dominance of non-framework building corals on Caribbean reefs affects carbonate production and future reef growth. Glob Change Biol 21:1153-1164

* Porter JW, Battey JF, Smith GJ (1982) Perturbation and change in coral reef communities. Proc Natl Acad Sci USA 79:1678-1681

* Precht WF, Aronson RB (2004) Climate flickers and range shifts of reef corals. Front Ecol Environ 2:307-314

* Precht WF, Robbart ML, Aronson RB (2004) The potential listing of Acropora species under the US Endangered Species Act. Mar Pollut Bull 49:534-536

Precht WF, Deslarzes KJP, Hickerson EL, Schmahl GP, Nuttall MF, Aronson RB (2014) Back to the future: the history of acroporid corals at the Flower Garden Banks, Gulf of Mexico, USA. Mar Geol 349:152-161

Precht WF, Gintert BE, Robbart ML, Fura R, van Woesik R (2016) Unprecedented disease-related coral mortality in southeastern Florida. Sci Rep 6:31374

* Richey JN, Poore RZ, Flower BP, Quinn TM (2007) 1400 yr multiproxy record of climate variability from the northern Gulf of Mexico. Geology 35:423-426

Ruzicka R, Colella M, Semon K, Brinkhuis V and others (2010) CREMP 2009 final report. Fish and Wildlife Research Institute, Florida Fish and Wildlife Conservation Commission, Saint Petersburg, FL

* Ruzicka RR, Colella MA, Porter JW, Morrison JM and others (2013) Temporal changes in benthic assemblages on Florida Keys reefs 11 years after the 1997/1998 El Niño. Mar Ecol Prog Ser 489:125-141

* Sale PF, Agardy T, Ainsworth CH, Feist BE and others (2014) Transforming management of tropical coastal seas to cope with challenges of the 21st century. Mar Pollut Bull 85:8-23

Sammarco PW, Atchison AD, Boland GS (2004) Expansion of coral communities within the Northern Gulf of Mexico via offshore oil and gas platforms. Mar Ecol Prog Ser 280: 129-143

* Schoepf V, Grottoli AG, Warner ME, Cai WJ and others (2013) Coral energy reserves and calcification in a high$\mathrm{CO}_{2}$ world at two temperatures. PLOS ONE 8:e75049

Serrano X, Baums IB, O'Reilly K, Smith TB and others (2014) Geographic differences in vertical connectivity in the Caribbean coral Montastraea cavernosa despite high levels of horizontal connectivity at shallow depths. Mol Ecol 23:4226-4240 
Shaver EC, Silliman BR (2017) Time to cash in on positive interactions for coral restoration. PeerJ 5:e3499

Shearer TL, Porto I, Zubillaga AL (2009) Restoration of coral populations in light of genetic diversity estimates. Coral Reefs 28:727-733

Shinn EA, Jaap WC (2005) Field guide to the major organisms and processes building reefs and islands of the Dry Tortugas: the Carnegie Dry Tortugas Laboratory centennial celebration (1905-2005). US Geological Survey and Florida Fish and Wildlife Conservation Commission, St. Petersburg, FL

Shinn EA, Hudson JH, Halley RB, Lidz B (1977) Topographic control and accumulation rate of some Holocene coral reefs: South Florida and Dry Tortugas. Proc 3rd Int Coral Reef Symp 2:1-7

Shulzitski K, Sponaugle S, Hauff M, Walter KD, Cowen RK (2016) Encounter with mesoscale eddies enhances survival to settlement in larval coral reef fishes. Proc Natl Acad Sci USA 113:6928-6933

Snyder NFR, Derrickson SR, Beissinger SR, Wiley JW, Smith TB, Toone WD, Miller B (1996) Limitations of captive breeding in endangered species recovery. Conserv Biol 10:338-348

Spalding M, Burke L, Wood SA, Ashpole J, Hutchison J, zu Ermgassen P (2017) Mapping the global value and distribution of coral reef tourism. Mar Policy 82:104-113

Storlazzi CD, Reguero BG, Cole AD, Lowe E and others (2019) Rigorously valuing the role of U.S. coral reefs in coastal hazard risk reduction. US Geological Survey Open-File Report 2019-1027. https://doi.org/10.3133/ofr 20191027

Toth LT, van Woesik R, Murdoch TJT, Smith SR, Ogden JC, Precht WF, Aronson RB (2014) Do no-take reserves benefit Florida's corals? 14 years of change and stasis in the Florida Keys National Marine Sanctuary. Coral Reefs 33: 565-577

Toth LT, Kuffner IB, Stathakopoulos A, Shinn EA (2018) A 3000-year lag between the geological and ecological collapse of Florida's coral reefs. Glob Change Biol 24: 5471-5483

Editorial responsibility: David Richardson, Norwich, UK
Toth LT, Stathakopoulos A, Kuffner IB, Ruzicka RR, Colella MA, Shinn EA (2019) The unprecedented loss of Florida's reef-building corals and the emergence of a novel coral-reef assemblage. Ecology 100:e02781

*Uzoh FCC, Ritchie MW (1996) Crown area equations for 13 species of trees and shrubs in northern California and southwestern Oregon. Res Pap PSW-RP-227-Web, Pacific Southwest Research Station, Forest Service, US Department of Agriculture, Albany, CA. https://www.fs. fed.us/psw/publications/documents/psw_rp227/psw_rp 227.pdf (accessed 19 Sep 2019)

*van Oppen MJH, Gates RD, Blackall LL, Cantin N and others (2017) Shifting paradigms in restoration of the world's coral reefs. Glob Change Biol 23:3437-3448

*Vitousek PM, Mooney HA, Lubchenco J, Melillo JM (1997) Human domination of Earth's ecosystems. Science 277: 494-499

Wapnick CM, Precht WF, Aronson RB (2004) Millennialscale dynamics of staghorn coral in Discovery Bay, Jamaica. Ecol Lett 7:354-361

Wigley TML (2005) The climate change commitment. Science 307:1766-1769

Williams DE, Miller MW, Kramer KL (2008) Recruitment failure in Florida Keys Acropora palmata, a threatened Caribbean coral. Coral Reefs 27:697-705

Williams DE, Miller MW, Baums IB (2014) Cryptic changes in the genetic structure of a highly clonal coral population and the relationship with ecological performance. Coral Reefs 33:595-606

* Williams DE, Miller MW, Bright AJ, Pausch RE, Valdivia A (2017) Thermal stress exposure, bleaching response, and mortality in the threatened coral Acropora palmata. Mar Pollut Bull 124:189-197

Woodley JD, Chornesky EA, Clifford PA, Jackson JBC and others (1981) Hurricane Allen's impact on Jamaican coral reefs. Science 214:749-755

Y Yamano H, Sugihara K, Nomura K (2011) Rapid poleward range expansion of tropical reef corals in response to rising sea surface temperature. Geophys Res Lett 38: L04601

Submitted: July 18, 2020; Accepted: October 12, 2020

Proofs received from author(s): December 9, 2020 